\title{
Assessment of Comprehensive Environmental Pollution Index of Kurichi Industrial Cluster, Coimbatore District, Tamil Nadu, India - a Case Study
}

\author{
Ramasamy Rajamanickam", S. Nagan² \\ 1 Tamil Nadu Pollution Control Board, Chennai 600032, Tamil Nadu, India \\ 2 Department of Civil Engineering, Thiagarajar College of Engineering, Madurai 625015, Tamil Nadu, India \\ * Corresponding author's e-mail: rajmak20@yahoo.co.in
}

\begin{abstract}
Comprehensive Environmental Pollution Index (CEPI) is a rational number to characterize the quality of the environment at a given location following the algorithm of source, pathway, and receptor. As CEPI increases, there will be adverse effects on the receiving environment. Central Pollution Control Board (CPCB) has brought out revised criteria for evaluation of CEPI by replacing the criteria issued in 2010. The revised criteria are issued to overcome the subjectivity factors of health impact studies on humans, flora and fauna. Kurichi Industrial Cluster in Coimbatore District is an engineering industrial estate housing foundries, forging units, metal finishing and fabrication units. In January 2010, the Ministry of Environment and Forests, Government of India declared Kurichi as critically polluted area and imposed moratorium on new projects and for expansion of the existing units. This declaration was made based on the CEPI score which was calculated as more than 70 . Thereafter, the industries and the local stake holders have implemented various pollution control measures and hence the CEPI score has come down less than 70 and so the moratorium was lifted in October 2010. In this paper, the CEPI score is calculated based on the revised criteria and using the environmental quality monitoring data collected in April 2017. It is found that the CEPI score is below 70 which imply that the industrial units are operating and maintaining the pollution control measures consistently. However, taking a policy decision based on the CEPI score, one should be cautious on the adequacy of data and the parameters selected.
\end{abstract}

Keywords: comprehensive environmental pollution index, Kurichi industrial cluster, Coimbatore.

\section{INTRODUCTION}

Environmental pollution remains a serious issue in the developing world, affecting the lives of billions of people, reducing their life expectancy, and damaging children's growth and development. The World Health Organization (WHO) estimates that $25 \%$ of all deaths in the developing world can be directly attributed to environmental factors (CPCB, 2009). The problem of pollution and its corresponding adverse ecological impacts have been aggravated due to increasing industrial and other developmental activities. India, among other developing nations of the world, is facing the challenge of industrial pollution. This has made the constant surveillance of environmental characteristics a necessary task. There is an urgent need to identify critically polluted areas and identify their problematic dimensions. Accordingly, measures have to be taken to make the process of industrial development and economic growth more sustainable. Central Pollution Control Board (CPCB) has brought out a tool called Comprehensive Environmental Pollution Index (CEPI) to identify the problematic industrial areas in the country (CPCB, 2009). 


\section{COMPREHENSIVE ENVIRONMENTAL POLLUTION INDEX (CEPI)}

CEPI is a rational number to characterize the quality of the environment at a given location following the algorithm of source, pathway, and receptor. As CEPI increases, there will be adverse effects on the receiving environment. CEPI is a useful tool for environmental decision making by policymakers. The CEPI scoring methodology is given in Figure 1 (CPCB, 2016).

\section{Scoring Methodology}

The scouring system involves an algorithm that takes into account the basic selection criteria. This approach is based on the basic hazard assessment logic as summarized below. Hazard = pollutant source, pathways, and receptor. CEPI is calculated separately for air, water, and land of the industrial cluster. To calculate various factors contributing to sub-indices and their values, the following procedure should be followed (Richard, 1995 and Rao, 1996).

A: Determining critical pollutants. Three most critical pollutants are to be considered for calculation and these are selected in the beginning of the process. The pollutants are divided into three groups, that is, A, B, and C. This information can be obtained from the criteria for comprehensive environmental assessment of Industrial Clusters issued by CPCB in December 2009 and a revised CEPI Version 2016. Pollutants belonging to Group $\mathrm{C}$ are more critical than those belonging to Group B, which is more critical than those in Group A. In cases with more than three pollutants in the same category exist, the ones with higher concentrations in the surroundings would be considered critical (CPCB, 2010).

\section{Factor $A 1$ - presence of toxin}

Group A - pollutants / chemicals that are not assessed as acute or systemic $=1$. Group B - organics / pollutants / chemicals that are probable carcinogens (USEPA Class 2 and 3) or substances with some systemic toxicity. e.g. VOC's, PAHs, PCBs, air pollutants such as $\mathrm{PM}_{10}$ and $\mathrm{PM}_{2.5}=2$. Group C - known carcinogens or chemicals with significant systemic or organ system toxicity. e.g. vinyl chloride, benzene, lead, radionuclide, hexachromium, cadmium, organophosphate pesticides $=3$. For the assessment purpose upto three most critical pollutants and two secondary pollutants are to be taken.

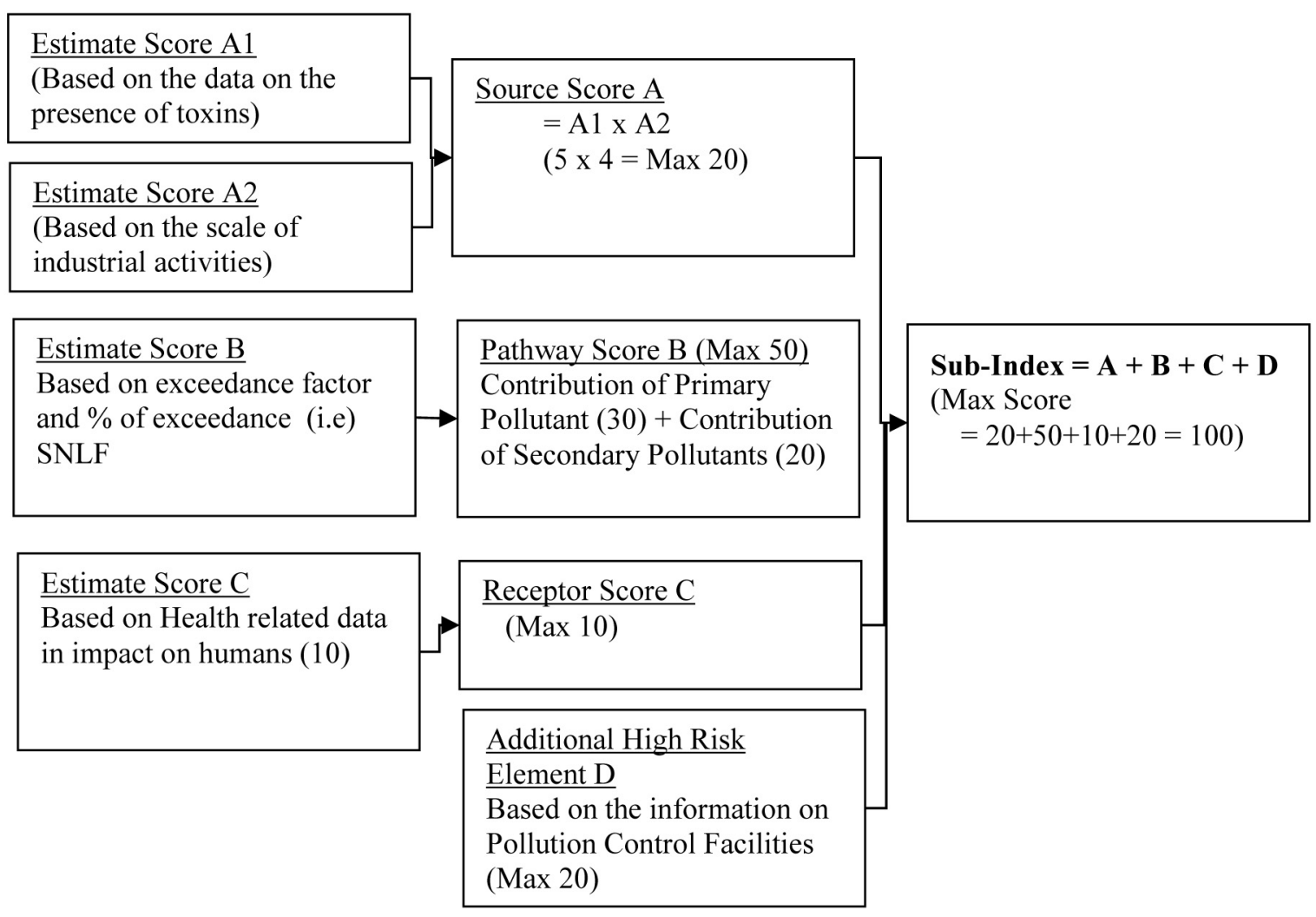

Figure 1. CEPI score calculation methodology 
Selection of criteria pollutants (critical or primary pollutants): Option 1: 3 pollutants relevant with the area depending on the nature of industrial activity (preferable option /method). Option 2: up to 3 most critical pollutants depending on the concentration and exceedance. The maximum contribution by the primary pollutant is 3 .

Selection of secondary pollutants: Based on the nature of the toxins, the contribution value of pollutant is given in Table 1 .

Maximum contribution of secondary pollutants $=2.00$

Maximum score of $\mathrm{A} 1=3+2=5$

\section{Factor A2 - scale of industrial activities}

Note: R17 - 17 categories of highly polluting industries, R 54 - red category industries as notified by CPCB.

Score A $=$ A1 $\times$ A2 $(\max$ score $=5 \times 4=20)$

B: Level of exposure. A surrogate number which will represent level of exposure (SNLF) is calculated using \% violation of ambient pollutant concentration, which is calculated as SNLF $=$ (no. of samples exceeded/ total no. of samples) $\times$ (exceedance factor). The value of Factor B for primary and secondary pollutant based on SNLF is given in Table 3.

Maximum contribution of primary pollutant $=30$ and maximum contribution of secondary pollutants $=20$. Hence maximum of Score $B=$ $30+20=50$

Table 1. Toxicity and contribution value of secondary pollutants

\begin{tabular}{|c|c|}
\hline $\begin{array}{c}\text { Group of toxicity of } \\
\text { each of the secondary } \\
\text { pollutants }\end{array}$ & $\begin{array}{c}\text { Contribution value for each } \\
\text { of the pollutant }\end{array}$ \\
\hline Group A & 0.25 \\
\hline Group B & 0.50 \\
\hline Group C & 1.00 \\
\hline
\end{tabular}

Table 2: Scale of industrial acidities and the contribution value

\begin{tabular}{|l|c|}
\hline \multicolumn{1}{|c|}{ Scale of industrial activities } & Value \\
\hline Large industrial activities : If there are > 10 R17 & \\
per 10 sq km area or fraction (OR) > 2 R17 + 10 & 4 \\
R54 per 10 sq km area or fraction (OR) > 100 & \\
R54 per 10 sq km area or fraction & \\
\hline $\begin{array}{l}\text { Moderate industrial activities: If there are 2 to 10 } \\
\text { R17 per } 10 \text { sq km area or fraction (OR) 10-100 } \\
\text { R54 per 10 sq km area or fraction }\end{array}$ & 2.5 \\
\hline $\begin{array}{l}\text { Limited industrial activities: Else there is any } \\
\text { industry within } 10 \text { sq km area or fraction }\end{array}$ & 1 \\
\hline
\end{tabular}

C: Receptor. The score value of Factor C depends on impact on human health (Table 4). For this purposes the health data of the previous five years from 3 to 5 major hospitals in the area shall be considered.

- \% increase is evaluated based on the total no. of cases recorded during two consecutive years.

- For air environment, total no. of cases related to Asthma, Bronchitis, Cancer, Acute respiratory infections etc. are to be considered.

- For surface water / ground water environment, cases related to gastroenteritis, diarrhea, renal (kidney) malfunction, cancer etc are to be considered.

D: Additional high risk element. Additional high risk element refers to inadequacy of pollution control measures for large scale, medium and small scale industries and also due to unorganized sector. It is cumulative of Effluent Treatment Plants (ETPs), Common Effluent Treatment Plants (CETPs), Air Pollution Control Devises (APCDs) and unorganized waste disposal. Max. score $=20$.

Inadequate facilities $\geq 10 \%$ units deficient in terms of design/ operation and maintenance of pollution control in case of small and medium scale industries (OR) $>2 \%$ units deficiency in terms of design/ operation and maintenance of pollution control in case of large scale industries or common facilities. The status report (last two years) shall be used for the purpose of deciding the score for adequacy.

\section{Evaluation of the Ambient Air Index / Surface Water Index / Ground Water Index (sub-index)}

After calculating A, B, C and D; calculate the sub index score: sub-index score $=(\mathbf{A}+\mathbf{B}+\mathbf{C}+$ D). Sub index scores are to be calculated for each of the individual environmental components that is, air environment, surface water environment, and soil \& ground water environment separately.

\section{Calculation of the aggregated CEPI}

The aggregated CEPI score can be calculated:

$$
\text { CEPI }=i_{m}+\left\{\left(100-i_{m}\right) \cdot\left(i_{2} / \mathbf{1 0 0}\right) \cdot\left(i_{3} / \mathbf{1 0 0}\right)\right\}
$$

Where, $\mathrm{i}_{\mathrm{m}}$ : maximum sub index; and $\mathrm{i}_{2}$, and $\mathrm{i}_{3}$ are sub indices for other media. If the CEPI score exceeds 70 , the industrial cluster is treated as critically polluted, if the CEPI score is 60-70, the industrial cluster is treated as severely polluted. 
Table 3. Factor B value for primary and secondary pollutants

\begin{tabular}{|c|c|c|c|}
\hline \multirow{2}{*}{ Range of SNLF } & \multirow{2}{*}{ Category } & \multicolumn{2}{|c|}{ Score value of Factor B } \\
\hline & & Primary pollutant & Secondary pollutant \\
\hline 0 (For $\mathrm{EF}<0.75)$ & Low & 0 & 0 \\
\hline $0($ For $0.75<\mathrm{EF}<0.80)$ & Low & 1.5 & 0.5 \\
\hline $0($ For $0.80<\mathrm{EF}<0.85)$ & Low & 3.0 & 1 \\
\hline $0($ For $0.85<\mathrm{EF}<0.90)$ & Low & 4.5 & 1.5 \\
\hline 0 (For $0.90<\mathrm{EF}<0.95)$ & Low & 6.0 & 2 \\
\hline $0($ For $0.95<\mathrm{EF}<1.0)$ & Low & 7.5 & 2.5 \\
\hline$<0.05$ & Moderate & 8.25 & 2.75 \\
\hline 0.05 to $<0.1$ & Moderate & 9.0 & 3 \\
\hline 0.1 to $<0.15$ & Moderate & 9.75 & 3.25 \\
\hline 0.15 to $<0.2$ & Moderate & 10.50 & 3.50 \\
\hline 0.2 to $<0.25$ & Moderate & 11.25 & 3.75 \\
\hline 0.25 to $<0.30$ & Moderate & 12 & 4.0 \\
\hline 0.30 to $<0.35$ & Moderate & 12.75 & 4.25 \\
\hline 0.35 to $<0.4$ & Moderate & 13.5 & 4.5 \\
\hline 0.40 to $<0.45$ & Moderate & 14.25 & 4.75 \\
\hline 0.45 to $<0.5$ & Moderate & 15 & 5 \\
\hline 0.5 to $<0.55$ & High & 15.75 & 5.25 \\
\hline 0.55 to $<0.60$ & High & 16.50 & 5.50 \\
\hline 0.6 to $<0.65$ & High & 17.25 & 5.75 \\
\hline 0.65 to $<0.7$ & High & 18 & 6.0 \\
\hline 0.7 to $<0.75$ & High & 18.75 & 6.25 \\
\hline 0.75 to $<0.80$ & High & 19.50 & 6.50 \\
\hline 0.80 to $<0.85$ & High & 20.25 & 6.75 \\
\hline 0.85 to $<0.90$ & High & 21.0 & 7 \\
\hline 0.90 to $<0.95$ & High & 21.75 & 7.25 \\
\hline 0.95 to $<1$ & High & 22.5 & 7.5 \\
\hline 1.0 and above & Critical & 30 & 10 \\
\hline
\end{tabular}

Table 4. Factor $\mathrm{C}$ score value based on $\%$ of increase in human health cases

\begin{tabular}{|c|c|}
\hline$\%$ of increase in cases & Score \\
\hline$<5 \%$ & 0 \\
\hline $5-10 \%$ & 5 \\
\hline$>10 \%$ & 10 \\
\hline
\end{tabular}

\section{MATERIALS AND METHODS}

\section{Kurichi Industrial Cluster}

Kurichi Industrial Cluster is located at 10'55'11" N Latitude and 7657'35" Longitude. The Industrial cluster is $7 \mathrm{KM}$ away on South from Coimbatore City on Coimbatore - Pollachi National Highway NH-209 (TNPCB, 2011). In this industrial cluster there are two industrial estates, one is SIDCO Industrial Estate developed by the Tamil Nadu State Government and another one is developed by private. This industrial cluster spreads over an area of 180 acres. The location map is given in Figure 2. There are 286 industries are in operation. Most of the industries are engineering industries with lathe drilling operation and few foundry units. There are no major water consuming and trade effluent generation industries in this cluster. There is no water body exist within and $2 \mathrm{~km}$ surrounding of the Kurichi industrial cluster. River Noyyal is located at $3 \mathrm{~km}$ on North direction and Kurichi lake is located at $2.5 \mathrm{~km}$ in the North West direction. There are hospitals, educational institutions located in the $2 \mathrm{KM}$ surrounding area.

\section{Source of pollution}

Water pollution. In the industrial cluster majority of the industries are engineering and foundry units. There is no generation of trade effluent from the units. Few surface coating units engaged in electroplating operations disposes the treated trade effluent through solar evaporation. The scrubbing effluent from the foundries is disposed 

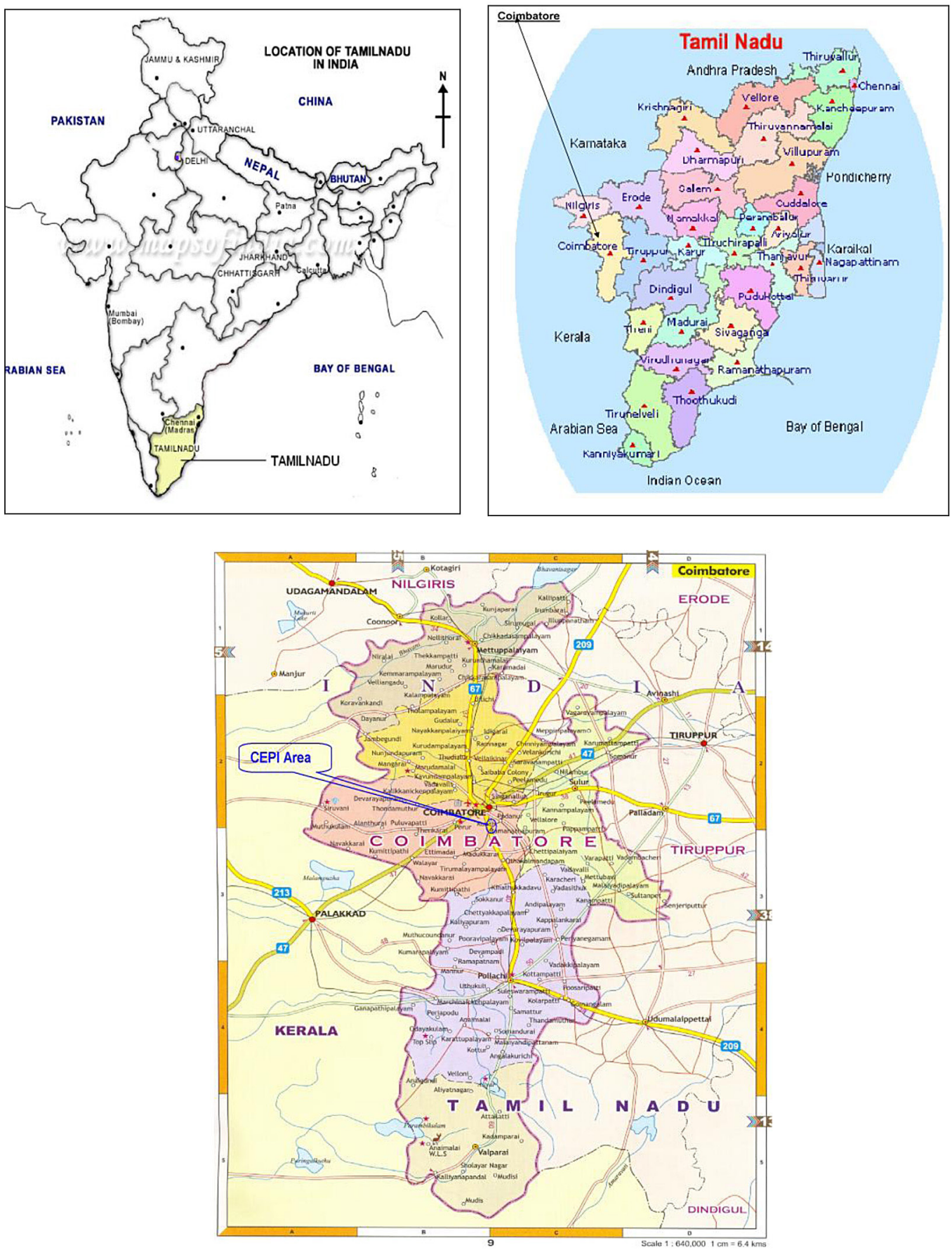

Figure 2. Location map of Kurichi Industrial Cluster, Coimbatore

through solar evaporation pan. The industries are labour intensive. The sewage generated from the units are collected and treated in septic tank provided by individual units.

Air pollution. In the industrial cluster, the major air pollutant is particulate matter let-out from foundries. The Heavy vehicle movement in the National Highway also contribute for air pollution. Sulphur di oxide, oxides of nitrogen and carbon monoxide emissions are let-out from the foundries operating with cupola furnaces, oil fired furnaces, forging unit, lead recovery unit (World Bank Group, 1998). The possible lead emission is from the lead recovery unit and vehicle movement. The industries have provided necessary air pollution control measures. The foundries with induction furnace and cupola furnaces have provided bag filter and wet scrubber attached with stack. Shot blasting machines are provided with bag filter and stack.

Land pollution. There is no major hazardous waste generating industries in Kurichi indus- 
trial cluster. However the hazardous waste such as used oil / waste oil, effluent treatment plant sludge are collected and disposed off complying with hazardous and other wastes (Management and Transboundary Movement) rules 2016.

\section{Assessment of CEPI for Kurichi Industrial Cluster}

In January 2010, the Ministry of Environment and Forests (MoEF), Government of India has declared 43 Industrial clusters in the courtney as critically polluted area who's CEPI score is more than 70 . The MoEF has imposed a moratorium and totally banned for setting of new industries and for the expansion of existing industries in these industrial clusters. Kurichi Industrial Cluster is one among them (MoEF, Jan. 2010). The CEPI score of Kurichi industrial complex was 72.38. Subsequently, the industries in the Kurichi area have implemented various pollution control measures and hence the CEPI score has come down below 70. Hence in October 2010, the MoEF have lifted the moratorium to the Kurichi Industrial Cluster subject one of the conditions that the environmental quality shall be monitored once in six months and the CEPI score shall be calculated. If the score exceeds 70, moratorium will be re-imposed (MoEF, Oct. 2010). Based on the above directions, Tamil Nadu Pollution Control Board (TNPCB) conducts ambient air quality; surface water quality and ground water quality survey and calculate CEPI score. In the recent past the survey was conducted in the month of April 2017. Using this data, the CEPI calculation is presented below.

Source (score A). The criteria pollutant and secondary pollutants chosen for the calculation water, air and land environment is given in Table 6. The parameters selected in year 2010 for assessment of CEPI are taken for this calculation also to maintain uniformity and for comparison. A1 is assigned based on the toxicity of the parameter (Harris and Joseph, 1991). For water environment, River Noyyal and Kurichi lake water quality is considered. For land environment, the ground water quality is considered. In Kurichi Industrial cluster there is no 17 categories of highly polluting industries. There are 45 Nos. of red category units, 32 orange category units and 192 green category units (TNPCB, 2010). As per the CPCB guidelines Kurichi Industrial cluster activity is considered as moderate. Hence A2 value is taken as 2.5.

Pathway (score B). The level of exposure is calculated based on the SNLF value (Mervyn, 1998).

Receptor (score C). Since data on the impact on human health due to this industrial cluster is not available, the value is taken as 5 (Rajamanickam, 2014).

Additional Risk Factor (score D). All the industries in the Kurichi industrial cluster have adequately designed / operated and maintained pollution control facilities but the common facilities such as common effluent treatment plants

Table 5. Factor D score based on adequacy of pollution control measures

\begin{tabular}{|c|c|c|c|c|}
\hline No. & Large scale industries & Large scale industries & Large scale industries & Score \\
\hline 1 & Adequate & Adequate & Adequate & 0 \\
\hline 2 & Adequate & Inadequate & Adequate & 10 \\
\hline 3 & Adequate & Adequate & Inadequate & 15 \\
\hline 4 & Adequate & Inadequate & Inadequate & 20 \\
\hline 5 & Inadequate & Inadequate & Inadequate & \\
\hline
\end{tabular}

Table 6. Criteria and secondary pollutants chosen for the CEPI score calculation

\begin{tabular}{|l|c|c|c|c|c|c|}
\hline \multirow{2}{*}{ Category of pollutant } & \multicolumn{2}{|c|}{ Air environment } & \multicolumn{2}{c|}{ Water environment } & \multicolumn{2}{c|}{ Land environment } \\
\cline { 2 - 7 } & Pollutant & Group & Pollutant & Group & Pollutant & Group \\
\hline Criteria pollutant - 1 & nickel & $\mathrm{C}$ & COD & $\mathrm{B}$ & TDS & $\mathrm{A}$ \\
\hline Criteria pollutant -2 & $\mathrm{PM}_{2.5}$ & $\mathrm{~B}$ & $\begin{array}{c}\text { nitrate- } \\
\text { nitrogen }\end{array}$ & $\mathrm{B}$ & fluoride & $\mathrm{A}$ \\
\hline Criteria pollutant -3 & $\mathrm{PM}_{10}$ & $\mathrm{~B}$ & total iron & $\mathrm{A}$ & nitrate & $\mathrm{B}$ \\
\hline Secondary pollutant -1 & $\mathrm{SO}_{2}$ & $\mathrm{~A}$ & $\mathrm{BOD}$ & $\mathrm{A}$ & $\begin{array}{c}\text { total } \\
\text { hardness }\end{array}$ & $\mathrm{A}$ \\
\hline Secondary pollutant -2 & $\mathrm{NO}_{x}$ & $\mathrm{~B}$ & TDS & $\mathrm{A}$ & total iron & $\mathrm{A}$ \\
\hline
\end{tabular}


(CETP)/Common Hazardous Waste Disposal Facilities (CHWDF) are having inadequate in capacity or operation / maintenance. In Kurichi, there is no CETP and CHWDF. Hence the score $\mathrm{D}$ is taken as 5 .

\section{RESULTS AND DISCUSSION}

The aggregated CEPI Score $=i_{m}+\left\{\left(100-i_{m}\right)\right.$ $\left.x\left(i_{2} / 100\right) \times\left(i_{3} / 100\right)\right\}=56.25+\{(100-56.25) \times$ $(34.12 / 100) \times(51.25 / 100)\}=63.90$. It is given in Table 11. The reduction in CEPI score is due to the implementation of action plan for improvement environmental quality and continual effi- cient operation and maintenance of the pollution control measures by the industries.

\section{CONCLUSIONS}

CEPI provides a comprehensive tool for determining the environmental problems of industrial cluster, which can further be used to improve the mitigation facilities. The source-pathway-receptor approach covers the basic linkages in the ecological process. The perfection depends on the consistency in pollution data available, regular environmental monitoring for data collection, presence of evidences of adverse impact on hu-

Table 7. Ambient air quality in the vicinity of Kurichi Industrial Cluster

\begin{tabular}{|c|c|c|c|c|c|c|c|c|}
\hline \multirow{3}{*}{ Parameters } & \multicolumn{6}{|c|}{ Sampling locations } & \multirow{3}{*}{ Average } & \multirow{3}{*}{ NAAQS } \\
\hline & \multicolumn{3}{|c|}{ Indo Shell Mould Ltd - unit II } & \multicolumn{3}{|c|}{ SIDCO office } & & \\
\hline & 1 & II & III & I & II & III & & \\
\hline Particulate matter $\left(\mathrm{PM}_{2.5}\right)$ in $\mu \mathrm{g} / \mathrm{m}^{3}$ & 51.5 & 74.8 & 46.2 & 29.0 & 31.0 & 33.5 & 44.33 & 60 \\
\hline Particulate matter $\left(\mathrm{PM}_{10}\right)$ in $\mu \mathrm{g} / \mathrm{m}^{3}$ & 93.6 & 130.4 & 87.7 & 61.0 & 65.0 & 74.6 & 85.38 & 100 \\
\hline Sulphur of Oxide $\left(\mathrm{SO}_{2}\right)$ in $\mu \mathrm{g} / \mathrm{m}^{3}$ & 16.3 & 19.4 & 14.8 & 6.6 & 4.3 & 7.8 & 11.5 & 80 \\
\hline Oxides of Nitrogen $\mathrm{NO}_{x}$ in $\mu \mathrm{g} / \mathrm{m}^{3}$ & 31.7 & 33.0 & 26.8 & 12.2 & 13.6 & 16.7 & 22.33 & 80 \\
\hline Ozone $\left(\mathrm{O}_{3}\right)$ in $\mu \mathrm{g} / \mathrm{m}^{3}$ & 27.0 & 19.3 & 20.7 & 16.0 & 13.7 & 23.7 & 20.06 & 180 \\
\hline Ammonia $\left(\mathrm{NH}^{3}\right)$ in $\mu \mathrm{g} / \mathrm{m}^{3}$ & 30.4 & 32.2 & 25.4 & 16.3 & 20.8 & 22.3 & 24.57 & 400 \\
\hline Nickel in $\mathrm{ng} / \mathrm{m}^{3}$ & 6.7 & 8.7 & 9.7 & 6.8 & $\mathrm{BDL}$ & 6 & 7.58 & 20 \\
\hline
\end{tabular}

Source: TNPCB. NAAQS - National Ambient Air Quality Standards (CPCB, 2010)

Table 8. Surface water quality of the water bodies nearby Kurichi Industrial Cluster

\begin{tabular}{|c|l|c|c|c|c|}
\hline \multirow{2}{*}{ No. } & \multirow{2}{*}{ Parameters } & \multicolumn{3}{|c|}{ Sampling location } & \multicolumn{2}{c|}{$\begin{array}{c}\text { Standard } \\
\text { (IS:2296-1982 } \\
\text { Class C) }\end{array}$} \\
\cline { 3 - 6 } & & Kurichi Lake & Noyyal River & Average & $6.5-8.5$ \\
\hline 1 & pH & 7.1 & 7.4 & 7.25 & 0.1 \\
\hline 2 & Oil \& Grease & $<2$ & $<2$ & $<2$ & - \\
\hline 3 & Total Suspended Solids & 12 & 18 & 15 & 4 \\
\hline 4 & Dissolved Oxygen & 2 & 1.6 & 1.8 & 3 \\
\hline 5 & Bio-chemical Oxygen Demand & 40 & 56 & 48 & - \\
\hline 6 & Chemical Oxygen Demand & 224 & 266 & 245 & - \\
\hline 7 & Total Dissolved Solids & 1820 & 2380 & 2100 & 50 \\
\hline 8 & Nitrate-Nitrogen & $\mathrm{BDL}$ & 0.88 & 0.88 & - \\
\hline 9 & Total Iron & 1.81 & 1.06 & 1.44 & 1.5 \\
\hline 10 & Free Ammonia & 8.7 & 11.2 & 9.95 & 400 \\
\hline 11 & Fluoride as $\mathrm{F}$ & 0.26 & 0.34 & 0.3 & - \\
\hline 12 & Sulphate as SO $\mathrm{SO}_{4}$ & 26.7 & 123.3 & 75 & - \\
\hline 13 & Sulphide as $\mathrm{H}_{2} \mathrm{~S}$ & 2.2 & 3.2 & 2.7 & - \\
\hline 14 & Total Hardness & 380 & 818 & 599 & - \\
\hline 15 & Total Ammonia & 14.8 & 19.4 & 17.1 & - \\
\hline 16 & Total Nitrogen & 19.6 & 25.5 & 22.55 & \\
\hline 17 & Chloride & 674 & 716 & 695 & \\
\hline
\end{tabular}

Source: TNPCB. Note: All parameters in mg/L except pH. BDL: Below detectable limit. IS 2296 - 1982: Tolerance limits for inland surface waters subject to pollution - Class C: Drinking water source with conventional treatment followed by disinfection. 
Table 9. Ground water quality in the Kurichi Industrial Cluster

\begin{tabular}{|c|c|c|c|c|c|}
\hline \multirow[b]{2}{*}{ No. } & \multirow[b]{2}{*}{ Parameters } & \multicolumn{2}{|c|}{ Sampling location } & \multirow[b]{2}{*}{ Average } & \multirow{2}{*}{$\begin{array}{c}\text { Standard } \\
\text { IS 10500-1991 }\end{array}$} \\
\hline & & $\begin{array}{c}\text { Surya Industries } \\
\text { Bore Well }\end{array}$ & $\begin{array}{l}\text { Indo Shell Mould Ltd, } \\
\text { Unit II Bore Well }\end{array}$ & & \\
\hline 1 & $\mathrm{pH}$ & 7.4 & 7.2 & 7.3 & $6.5-8.5$ \\
\hline 2 & Oil \& grease & $<2$ & $<2$ & $<2$ & - \\
\hline 3 & Biochemical Oxygen Demand & $<2$ & $<2$ & $<2$ & - \\
\hline 4 & Chemical Oxygen Demand & $<4$ & $<4$ & $<4$ & - \\
\hline 5 & Total Dissolved Solids & 954 & 1682 & 1318 & 500 \\
\hline 6 & Fluoride & 0.14 & 0.13 & 0.135 & 1.0 \\
\hline 7 & Total nitrogen & 107 & 111 & 109 & 45 \\
\hline 8 & Total hardness as $\mathrm{CaCO}_{3}$ & 445 & 741 & 593 & 300 \\
\hline 9 & Total Iron & 0.08 & 0.06 & 0.07 & 0.3 \\
\hline 10 & Free ammonia as $\mathrm{NH}_{3}$ & $\mathrm{BDL}$ & $\mathrm{BDL}$ & $\mathrm{BDL}$ & - \\
\hline 11 & Dissolved phosphate & 0.1 & 3.49 & 1.80 & - \\
\hline 12 & Total phosphorous & 0.12 & 3.56 & 1.84 & - \\
\hline 13 & Chloride & 145 & 449 & 297 & 250 \\
\hline
\end{tabular}

Source: TNPCB. Note: All parameters in mg/L except pH. BDL: Below detectable limit. IS: 10500 - 1991: Tolerance limits for inland surface waters subject to pollution - desirable limit

Table 10. Sub-index for air, water and land environment

\begin{tabular}{|l|c|c|c|c|c|c|c|c|c|}
\hline Type of environment & A1 & A2 & A & B1 & B2 & B & C & D & $\begin{array}{c}\text { Sub-index } \\
\text { score }\end{array}$ \\
\hline Air environment & 3.75 & 2.5 & 9.375 & 9.75 & 0 & 9.75 & 5 & 10 & 34.13 \\
\hline Water environment & 2.5 & 2.5 & 6.25 & 15 & 20 & 35 & 5 & 5 & 51.25 \\
\hline Land environment & 2.5 & 2.5 & 6.25 & 30 & 10 & 40 & 5 & 5 & 56.25 \\
\hline
\end{tabular}

Table 11. CEPI score

\begin{tabular}{|c|c|c|c|c|}
\hline $\begin{array}{c}\text { Air environment } \\
\text { sub-index score }\left(\mathrm{i}_{1}\right)\end{array}$ & $\begin{array}{c}\text { Water environment } \\
\text { sub-index score }\left(\mathrm{i}_{2}\right)\end{array}$ & $\begin{array}{c}\text { Land environment } \\
\text { sub-index score }\left(\mathrm{i}_{3}\right)\end{array}$ & $\begin{array}{c}\text { Maximum sub-index } \\
\text { score }\left(\mathrm{i}_{\text {max }}\right)\end{array}$ & CEPI score \\
\hline 34.13 & 51.25 & 56.25 & 56.25 & 63.90 \\
\hline
\end{tabular}

man or ecology. The estimation of CEPI should be a dynamic and ongoing process and continuous flow of additional data and information in assessing CEPI should be ensured. Therefore, the regulatory organizations should monitor the pollution level in the Kurichi industrial cluster on regular basis and ensure that the CEPI score should be at the lower level by way of effective implementation of pollution control and environmental protection measures.

\section{REFERENCES}

1. CPCB, 2009. Criteria For Comprehensive Environmental Assessment Industrial Clusters, Series EIAS/4/2009-10, December 2009.http://cpcb.nic. in/divisionsofheadoffice/ess/NewItem_151_Final_ Book1.pdf

2. CPCB, 2016. Final Document on Revised CEPI
Version-2016', No. B-29012/ESS(CPA)/2015-16/ April 26, 2016.http://www.cpcb.nic.in/upload/Latest/Latest_120_Directions_on_Revised_CEPI.pdf

3. CPCB, 2010. Pollution Control Acts, Rules and Notifications Issued Thereunder, Series PCLS/02/2010 (Sixth Edition), June 2010.

4. Cother R., 1995. Handbook for Environmental Risk Decision Making - Values, Perception \& Ethics, Lewis Publishers, Boca Raton, 1-580.

5. Greenebrg H.R. and Cramer J.J., 1991. Risk Assessment and Risk Management for the Chemical Process Industry, Stone \& Webster Engineering Corporation, Van Nostrand Reinhold, New York, 1-370.

6. Indian Standards, 1982. Tolerance limits for inland surface waters subjected to pollution, IS: 2296: 1982.

7. Indian Standards, 1991. Drinking Water Specification, IS: 10500: 1991

8. Petts J., 1999. Handbook of Environmental Impact Assessment, Vol. 1, Bookwell Science Ltd., Oxford. 
9. Richardson M.L., 1998. Risk Assessment of Chemicals in the Environment, Royal Society of Chemistry, London. 1-580.

10. MoEF, GOI, 2010. Office Memorandum J-11013/5/2010-IA.II(I) Dated 13th January, 2010. www.moef.nic.in

11. MoEF, GOI, 2010. Office Memorandum J-11013/5/2010-IA.II(I) Dated 26th October, 2010. www.moef.nic.in

12. Rajamanickam R. and Nagan S., 2014. Evaluation of Environmental Quality of SIPCOT Industrial Complex, Cuddalore, Tamil Nadu through CEPI, J.
Environ. Science \& Engin. 56(4), 383-398.

13. Kolluru R.V., Bartell S.M., Pitblado R.M. and Stricoff R.S., 1996. Risk assessment and Management Handbook, McGraw-Hill, Inc, New York, 1-660.

14. The World Bank Group, 1998. Pollution Prevention and Abetment Handbook - Towards Cleaner Production, The World Bank Group, Washington, D.C.

15. TNPCB, 2011. Action Plan for Critically Polluted Area Kurichi Industrial Cluster, Coimbatore.

16. TNPCB, 2017. Report of the survey conducted in the Kurichi Industrial Cluster, Coimbatore. 